\title{
Treatment of Lung Cancer-Related Intractable Hiccups Using Pulsed Radiofrequency: Clinical Experience
}

\author{
Suk Ju Cho, Ph.D. \\ Department of Anesthesiology and Pain Medicine, Jeju National University School of Medicine, Jeju, Korea
}

While most benign hiccups can be controlled with empirical therapy, intractable hiccups lasting longer than one month tend to have significant adverse effects with obscure etiology. Treatment strategies for intractable hiccups have not been established. Only a few sporadic cases of bilateral phrenic nerve blockage have been reported. Here, we report a case of intractable hiccups that lasted five weeks in a 56-year-old male patient with a lung cancer above the right diaphragm. We hypothesized that his intractable hiccups were caused by irritation and mass effect caused by the lung cancer. We performed an ultrasound-guided right unilateral phrenic nerve pulsed radiofrequency treatment, and the patient's intractable hiccups were successfully managed without complication.

Key Words: Hiccup, Lung neoplasms, Pulsed radiofrequency treatment, Ultrasonography
Received April 13, 2018

Revised August 15, 2018

Accepted August 24, 2018

\section{Correspondence to}

Suk Ju Cho

Department of Anesthesiology and

Pain Medicine, Jeju National University

School of Medicine, 15 Aran 13 gil, Jeju

63241, Korea

Tel: +82-64-717-2062

Fax: +82-64-717-2063

E-mail:sukjucho@gmail.com

\section{INTRODUCTION}

Hiccup is an abrupt and involuntary spasm of the diaphragm and intercostal muscles followed by sudden closure of the glottis (1). An intractable hiccup, defined as a persistent hiccup for more than one month, is a rare disorder that causes significant morbidity in patients with advanced cancers (2). While the known etiologies of hiccup in palliative cancer patients include side effect of chemotherapy, electrolytes derangements, esophagitis, and neoplastic involvement in the central nervous system, thorax, and abdominal cavity, the etiologies remain obscure in most cases (2). Because intractable hiccup is very difficult to be treated by conventional methods, such as holding a breath and drinking cold water, variable pharmacologic treatments have been researched, including anticonvulsants, dopamine antagonists, and methylphenidate or serotonin receptor agonists (3). Here, we describe the first case of an intractable hiccup in a patient with a lung cancer in the right lower lobe just above the diaphragm that was successfully treated by ultrasound (US) guided pulsed radiofrequency treatment (PRFT) of right phrenic nerve.

\section{CASE PRESENTATION}

A 56-year-old man presented with an intractable hiccup that began five weeks ago and persisted. He complained of difficulties in eating, sleeping, and daily business. The patient had been diagnosed with lung cancer (stage IVA). He had undergone palliative care due to poor pulmonary function resulting from smoking-related emphysematous lung. He has not undergone chemotherapy.

A chest X-ray showed a large round mass in the right lower lung field and intact diaphragm (Figure 1A). A computed tomography (CT) scan revealed a central necrosis of the mass and a pleural thickening with overgrowing fibrotic tissue which suggested a diaphragmatic invasion (Figure 1B). Labo- 

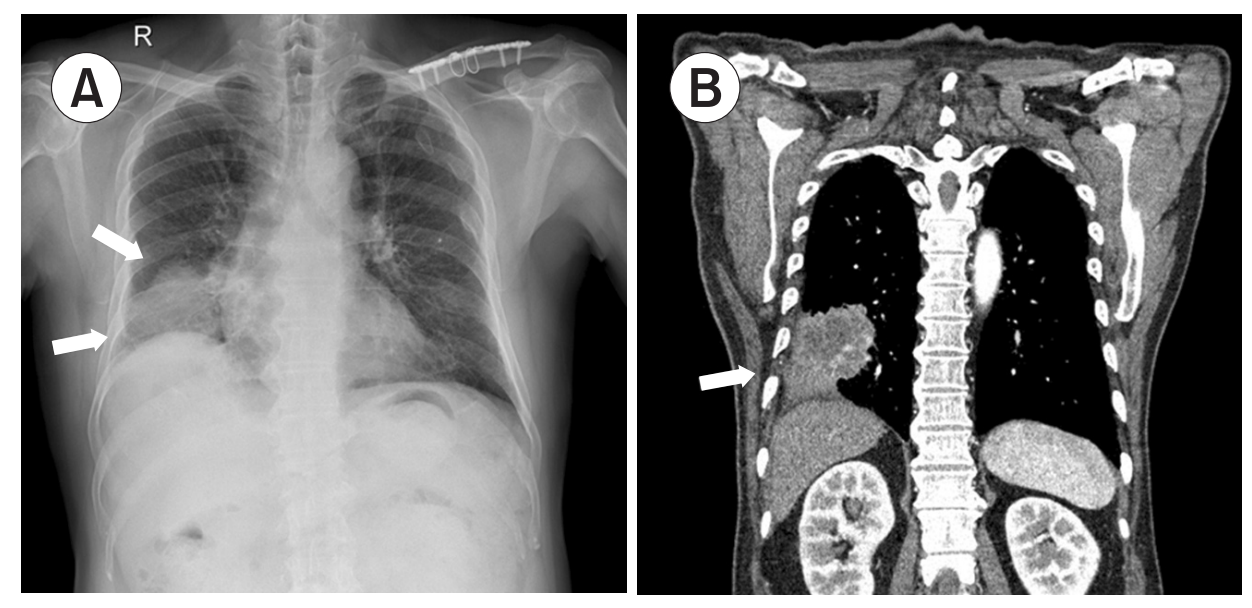

Figure 1. X-ray and computed tomography images at admission revealing an irregularshaped mass in the right lower lobe of a lung cancer patient. (A) Chest X-ray image; (B) Computed tomography image.

ratory findings on electrolytes were normal. Brain magnetic resonance image and abdominal CT scan revealed no specific abnormalities except a mild paralytic ileus. Although the patient was treated with metoclopramide, baclofen (up to 60 $\mathrm{mg} /$ day), midazolam, amitriptyline (up to $100 \mathrm{mg} /$ day), and gabapentin (up to $1,800 \mathrm{mg} /$ day) in various dosages and combinations, his hiccup persisted. Symptoms including fatigue, insomnia, and depressive mood were not improved.

To treat the intractable hiccup, a right-sided in-plane sonoguided phrenic nerve block was performed using linear high frequency transducer (M-Turbo, SonoSite Inc., USA) and a 22 $\mathrm{G} \times 50 \mathrm{~mm}$ needle. The right phrenic nerve was located slightly below the cricoid level where it was separated from the C5, C6, and C7 nerve roots. After syringe aspiration, $5 \mathrm{~mL}$ of $0.15 \%$ levobupivacaine were slowly injected around the target nerve using sono-guidance and real-time assessment of diffusion of the anesthetic solution. Ten minutes after the procedure, the intractable hiccup completely discontinued. However, hiccups recurred after two days. On the next day, phrenic nerve block procedure was repeated, but hiccups recurred after three days. We decided to perform PRFT with ultrasonography to relieve hiccups longer. After explaining the procedure, efficacy, and possible side effects of the PRFT to the patient, we put the patient in a supine position and turned his face to the left to have access to the right phrenic nerve. The skin was aseptically draped with betadine and placed a linear probe at a position 2 $\mathrm{cm}$ cephalad from the top of the clavicle to scan the anatomical structures of his neck. After discovering the phrenic nerves situated in the anterior surface of the anterior scalene muscle behind its fascia (Figure 2), the $10 \mathrm{~cm}$ radiofrequency needle

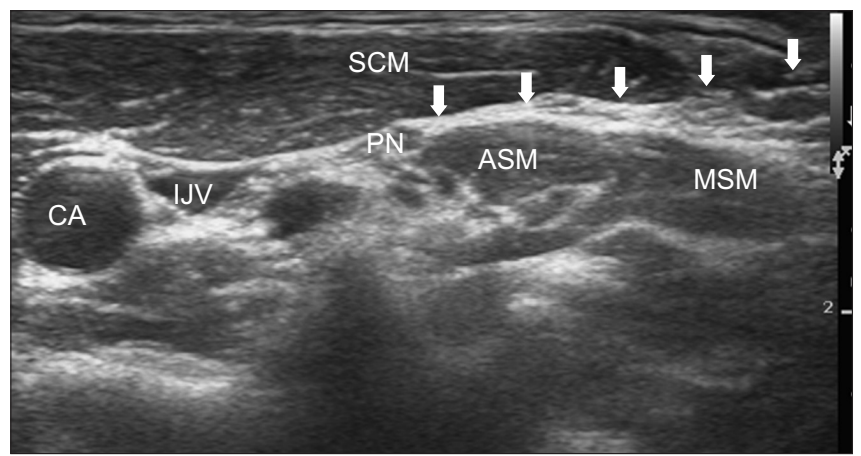

Figure 2. Ultrasound image of needle insertion showing the needle tip adjacent to phrenic nerve for nerve block. Needle is indicated by the white arrows.

PN: phrenic nerve, SCM: sternocleidomastoid muscle, ASM: anterior scalene muscle, MSM: middle scalene muscle, CA: carotid artery, IJV: internal jugular vein.

(SMK-C10 needle, NeuroTherm, USA) with a $5 \mathrm{~mm}$ active tip was slightly advanced as close as possible to the nerves by using ultrasound. Electrical nerve stimulation using radiofrequency lesion generator (Neuro N 50, Stockert GmbH, Germany) showed concordant in diaphragmatic movement of upper abdomen at $2 \mathrm{~Hz}$ and $0.5 \mathrm{~mA}$ which confirmed the proper localization of the radiofrequency electrode. After clarifying the location of the phrenic nerves once again, we performed PRFL for a total of 600 seconds at $42^{\circ} \mathrm{C}$ with stimulation intervals of $20 \mathrm{~ms} / \mathrm{sec}$. The patient was discharged from pain at clinic two hours after the procedure. The frequency and intensity of his hiccups gradually decreased during two weeks of follow-up.

The patient was followed-up for one month accompanying oral medication with baclofen $10 \mathrm{mg}$ and gabapentin 300 mg per day. His hiccups completely disappeared. A follow-up chest X-ray showed no complications such as elevation of the diaphragm. The patient did not complain aggravating dyspnea. 
At a 2-month follow up, his hiccups did not recur.

\section{DISCUSSION}

In daily life, most hiccup episodes are benign. They are usually acute and self-limited that typically cease within minutes (1). However, an intractable hiccup lasting for more than one month significantly impairs life quality, especially in cancer patients (4). Even though the pathogenesis of hiccup is complex through the hiccup reflex composed of afferent and efferent limbs and a central hiccup center, its evident pathophysiology is still unclear. The afferent limb is composed of vagus nerve, phrenic nerve, and a sympathetic chain arising from T6-T12 $(5,6)$. The sympathetic nervous system may play some role in the generation of hiccups, as they cease after administration of beta-receptor antagonist carvedilol (6). The vagus nerve irritation of the auricular branch of the vagus that innervates the auditory system can result in hiccups (7). The efferent limb is the phrenic nerve that is the primary motor input to the diaphragm (8). Brainstem centers independent of the respiratory center are thought to be responsible for hiccups (9). Hiccup may be induced by lung cancer itself or by irritating the phrenic nerve (7). In our case, the patient had a large mass with central necrosis just above the diaphragm. Inflammatory reactions from the cancer necrosis seemed to induce a fibrosis and adhesion between the parietal pleura and diaphragm which might have irritated the phrenic nerve.

Treatments for hiccup include non-pharmacological therapy, pharmacological therapy, and nerve block. Non-pharmacological therapy is used to inhibit afferent pathway of vagus nerve, such as holding a breath, drinking cold water, and carotid sinus massage (10). If non-pharmacological therapy is ineffective, variable drugs, including metoclopramide, chlorpromazine, amitriptyline, phenytoin, and valproic acid can be used (11). Recently, several literatures described the preferred approach for treating hiccups in cancer patients is through methylphenidate or serotonin (5-HT) 1A receptor agonist $(7,12)$. If these efforts are ineffective, other therapeutic approaches, such as acupuncture and phrenic nerve block can be tried $(8,13)$.

A nerve block guided by ultrasonography is a beneficial tool to directly look at the nerve and its surrounding anatomy. It needs local anesthetics because a needle is needed to be placed as close as possible to target nerves. We could find the phrenic nerve, therefore, we situated the needle exactly in front of the target nerve without injury to any other structures. However, Renes et al.(14) suggested that caution should be exercised in performing procedure in patients with severe pulmonary disorders because phrenic nerve block could induce a diaphragmatic paralysis which might result in respiratory distress (1517). We performed the phrenic nerve block only into the right diaphragm. Therefore, even if a diaphragmatic paralysis occurs, the probability of respiratory distress would be low. Our patient had no respiratory complications.

The mechanism of PRFT is by inhibiting evoked synaptic activity of excitatory $\mathrm{C}$-fiber in response to repetitive, burstlike stimulation of $\mathrm{A} \delta$-fiber, and changed structure of nerve tissue (18). Microstructure research has indicated that PRFT causes axonal changes more obviously in $\mathrm{C}$ fibers than that in in $A \alpha$ or $A \beta$ fibers, which is largely manifested within the mitochondria as micro-cytoskeletal edema, leading to an abnormality in ATP metabolism and ion channel and pump function, thereby blocking the pain transfer in relevant nerves (19). Pulsed mode radiofrequency (RF) lesioning is nondestructive. However, it can relieve pain by delivering an electrical field to neural tissue and short pulses of radiofrequency energy, producing central and peripheral neuromodulatory effects (18). Recent evidence suggests that the electrical field, rather than the heat lesion, is responsible for the clinical effect of RF. A placebo controlled, double blind study demonstrated that pulsed electrical fields could relieve pain and improve function in osteoarthritis (20). Pulsed RF may provide long lasting pain relief, reduce analgesic use, and provide satisfaction to patients (21). Furthermore, this procedure can be repeated. Pulsed RF is usually safe if the pain recurs because there was no clinical evidence of neural damage even though there is post-procedure discomfort and pain after PRFT (22). For these reasons, we performed PRFT rather than repeated conventional nerve block using local anesthetics. To date, only a few cases have been published on the subject involving $\mathrm{pa}^{-}$ tients with hiccup (23). In that previous reported case, intractable hiccups that had developed after coronary artery bypass graft for 7 years was relieved after PRFT of the phrenic nerves without any complication. However, this is a unique case of 
intractable hiccup in patient with lung cancer compared with previous case report.

In summary, evaluations on underlying diseases or causal facts should precede before treating intractable hiccup. If the etiology of the intractable hiccup is highly suspected to be associated with lung cancer near the diaphragm, a phrenic nerve PRFT guided by ultrasonography can be an alternative procedure to treat the intractable hiccup. The procedure can be performed simply and unilaterally that might provide effect and safe management for the hiccup.

\section{요약}

딸꾹질은 대개의 경우에는 특별한 처치 없이도 고식적인 방법으로 멈추지만, 한 달 이상 지속되는 지속성 딸꾹질은 생명을 위협할 정도 의 심각한 부작용을 초래한다. 특히 정확한 치료방법 또한 확립되어 있지 않고, 몇몇 보고에서 양측 횡격막 신경차단이 보고되어 있을 뿐 이다. 56세 남환의 우측 횡격막을 침범한 말기폐암환자에서 발생한 난치성 지속성 딸꾹질에 대해 박동성 고주파술을 시행하여 좋은 치 료 결과를 얻은 바, 문헌고찰과 함께 보고하고자 한다.

중심단어: 딸꾹질, 폐암, 박동성 고주파술, 초음파

\section{REFERENCES}

1. Rousseau P. Hiccups. South Med J 1995;88:175-81.

2. Calsina-Berna A, Garcia-Gomez G, Gonzalez-Barboteo J, Porta-Sales J. Treatment of chronic hiccups in cancer patients: a systematic review. J Palliat Med 2012;15:1142-50.

3. Marinella MA. Diagnosis and management of hiccups in the patient with advanced cancer. J Support Oncol 2009;7:122-7, 130.

4. Ripamonti C, Fusco F. Respiratory problems in advanced cancer. Support Care Cancer 2002;10:204-16.

5. Kahrilas PJ, Shi G. Why do we hiccup? Gut 1997;41:712-3.

6. Stueber D, Swartz CM. Carvedilol suppresses intractable hiccups. J Am Board Fam Med 2006;19:418-21.

7. Marechal R, Berghmans T, Sculier P. Successful treatment of intractable hiccup with methylphenidate in a lung cancer patient. Supportive Care Cancer 2003;11:126-8.

8. Choi GW, Kwak KH, Jeon YH, Hong JG. Treatment of postoperative intractable hiccup patient with unilateral phrenic nerve block: a case report. Korean J Anesthesiol 2006;50:592-5.

9. McAllister RK, McDavid AJ, Meyer TA, Bittenbinder TM. Recurrent persistent hiccups after epidural steroid injection and analgesia with bupivacaine. Anesth Analg 2005;100:1834-6.

10. Kolodzik PW, Eilers MA. Hiccups (singultus): review and approach to management. Ann Emerg Med 1991;20:565-73.

11. Homer JR, Davies JM, Amundsen LB. Persistent hiccups after attempted interscalene brachial plexus block. Reg Anesth Pain Med 2005;30:574-6.

12. Takahashi T, Murata T, Omori M, Tagaya M, Wada Y. Successful treatment of intractable hiccups with serotonin (5-HT) 1A receptor agonist. J Neurol 2004;251:486-7.

13. Liu FC, Chen CA, Yang SS, Lin SH. Acupuncture therapy rapidly terminates intractable hiccups complicating acute myocardial infarction. South Med J 2005:98:385-7.

14. Renes SH, van Geffen GJ, Rettig HC, Gielen MJ, Scheffer GJ. Ultrasound-guided continuous phrenic nerve block for persistent hiccups. Reg Anesth Pain Med 2010;35:455-7.

15. Petroianu G. Idiopathic chronic hiccup (ICH): phrenic nerve block is not the way to go. Anesthesiology 1998;89:1284-5.

16. Okuda Y, Kitajima T, Asai T. Use of a nerve stimulator for phrenic nerve block in treatment of hiccups. Anesthesiology 1998;88:525-7.

17. Bashein G, Robertson HT, Kennedy WF Jr. Persistent phrenic nerve paresis following interscalene brachial plexus block. Anesthesiology 1985;63:102-4.

18. Cahana A, Vutskits L, Muller D. Acute differential modulation of synaptic transmission and cell survival during exposure to pulsed and continuous radiofrequency energy. J Pain 2003;4:197-202.

19. Vatansever D, Tekin I, Tuglu I, Erbuyun K, Ok G. A comparison of the neuroablative effects of conventional and pulsed radiofrequency techniques. Clin J Pain 2008;24:717-24.

20. Thamsborg G, Florescu A, Oturai P, Fallentin E, Tritsaris K, Dissing S. Treatment of knee osteoarthritis with pulsed electromagnetic fields: a randomized, double-blind, placebo-controlled study. Osteoarthritis Cartilage 2005;13:575-81.

21. Munglani R. The longer term effect of pulsed radiofrequency for neuropathic pain. Pain 1999;80:437-9.

22. Rohof OJ. Radiofrequency treatment of peripheral nerves. Pain Pract 2002;2:257-60.

23. Kang KN, Park IK, Suh JH, Leem JG, Shin JW. Ultrasound-guided pulsed radiofrequency lesioning of the phrenic nerve in a patient with intractable hiccup. Korean J Pain 2010;23:198-201. 